\title{
Karabaş Otu (Lavandula stoechas) Yağının Sazan Balığı (Cyprinus carpio) Yemlerine İlavesinin Büyüme Performansı ve Bazı Kan Parametreleri Üzerine Etkileri
}

\author{
Sevdan Yılmaz \\ Çanakkale Onsekiz Mart Üniversitesi, Deniz Bilimleri ve Teknolojisi Fakültesi, Su Ürünleri Yetiştiriciliği Bölümü, \\ 17100/Çanakkale. \\ Sorumlu yazar: sevdanyilmaz@comu.edu.tr
}

Geliş Tarihi: 06.08.2018

Kabul Tarihi: 13.12.2018

\section{Öz}

$\mathrm{Bu}$ çalışmada, karabaş otu (Lavandula stoechas) yağının sazan, Cyprinus carpio balı̆̆ı yemlerine ilavesinin büyüme performansı, hematolojik ve serum biyokimyasal parametreleri üzerine etkileri araştırılmıştır. İzonitrojenik ve izokalorik olarak hazırlanan üç farklı diyet 0 (kontrol), 5 ve $10 \mathrm{~g} / \mathrm{kg}$ karabaş otu yağı ihtiva edecek şekilde formüle edilmiştir. Balıklar 60 gün boyunca deneme yemleriyle beslenmiştir. $5 \mathrm{~g} / \mathrm{kg}$ karabaş otu yağı ile beslenen sazan balıklarının deneme sonu ağırlığı, ağırlık artışı ve spesifik büyüme oranı kontrol yemi ile beslenen balıklara göre anlamlı derecede daha fazla artış göstermiştir $(\mathrm{p}<0,05)$. Sonuçlar, 5 ve $10 \mathrm{~g} \mathrm{~kg}^{-1} \mathrm{karabaş}$ otu yağı içeren diyetlerin kontrol diyetine göre kırmızı kan hücresi sayısı, hematokrit oranı (\%), serum total protein, albümin, globulin, trigliserit, kolesterol, alkalin fosfataz, glutamik oksaloasetik transaminaz, glutamik piruvik transaminaz ve laktat dehidrojenaz seviyelerini önemli ölçüde etkilemediğini göstermiştir $(p>0,05)$. Ancak, karabaş otu yağının $5 \mathrm{~g} / \mathrm{kg}$ oranında yeme ilavesi hemoglobin konsantrasyonunu olumlu yönde etkilemiştir $(\mathrm{p}<0,05)$. Ayrıca, $5 \mathrm{~g} / \mathrm{kg}$ karabaş otu yağı grubunda kontrol grubuna göre önemli derecede düşük serum glikoz seviyeleri belirlenmiştir $(\mathrm{p}<0,05)$. Sonuç olarak yeme $5 \mathrm{~g} / \mathrm{kg}$ oranında karabaş otu yağı ilavesi sazan balığının (C. carpio) gelişimini arttırabileceği bulunmuştur.

Anahtar Kelimeler: Sazan, karabaş otu (lavanta), hematoloji, serum biyokimyası, büyüme

\section{The Effects of Dietary Lavender (Lavandula stoechas) on Growth Performance and Some Blood Parameters of Common Carp (Cyprinus carpio)}

\section{Abstract}

The present study investigated the effects of dietary topped lavender (Lavandula stoechas) oil supplementation on growth performance, hematological and serum biochemical parameters of common carp, Cyprinus carpio. Three isonitrogenous and isocaloric diets were formulated to contain 0 (control), $5 \mathrm{and} 10 \mathrm{~g}$ of topped lavender oil $\mathrm{kg}^{-1}$ of fish feed. Fish were fed experimental diets for 60 days. Final weight, weight gain and specific growth rate of carp fed the $5 \mathrm{~g} \mathrm{~kg}^{-1}$ topped lavender oil diet were significantly greater than that of control diet $(\mathrm{p}<0.05)$. Results showed that the red blood cell count, hematocrit ratio $(\%)$, serum total protein, albumin, globulin, triglyceride, cholesterol, alkaline phosphatase, glutamic oxaloacetic transaminase, glutamic pyruvic transaminase, and lactate dehydrogenase levels were not significantly affected by diets containing $5 \mathrm{gnd} 10 \mathrm{~g}$ topped lavender oil compared to control diets $(\mathrm{p}>0.05)$. Supplementation of topped lavender oil at $5 \mathrm{~g} \mathrm{~kg}^{-1}$ positively influenced the hemoglobin concentration $(\mathrm{p}<0.05)$. Moreover, $5 \mathrm{~g} \mathrm{~kg}^{-1}$ topped lavender oil group had significantly lower values of serum glucose than control group $(\mathrm{p}<0.05)$. It was concluded that $5 \mathrm{~g} \mathrm{~kg}^{-1}$ topped lavender oil can enhance growth of common carp, C. carpio.

Keywords: Carp, topped lavender (lavender), hematology, serum biochemistry, growth

\section{Giriș}

Dünya sazan yetiştiriciliği miktarı 4,3 milyon tona ulaşmıştır (FAO, 2015). Sazan yetiştiriciliği esnasında birçok hastalık görülebilmektedir. Bu hastalıklar arasında bakteri kökenli olanlar önemli ekonomik kayiplara neden olabilmektedir (Hoole ve ark., 2008). Bakteriyel hastalıkların tedavisinde genellikle antibiyotik kullanılmaktadır. Ancak günümüzde antibiyotik kullanımı gerek çevre gerekse de insan üzerindeki zararlı etkileri nedeniyle yasaklanmakta veya kullanımı kısıtlanmaktadır ( $\mathrm{Ng}$ ve Koh 2017). Bu durum balık yetiştiriciliğinde antibiyotiğe alternatif ürün arayışını arttırmıştır. Yapılan çalışmalarda özellikle tıbbi bitki ve baharatların faydalı özellikleri ile balık gelişimine ve sağlığına yararlı etki gösterdiği rapor edilmiştir (Ramudu ve Dash 2013; Van 

üzerindeki etkileri son yıllarda önemli bir araştırma konusudur. Yeme ilave edilen tıbbi bitki yağlarının balıkların büyüme performansına, besin değerine, bağışıklık sistemine ve hastalık direnci üzerine olumlu etkileri olduğu bildirilmiştir (Yılmaz ve Ergün 2012; Ezzat Abd El-Hack ve ark., 2016; Baba ve ark., 2017; da Cunha ve ark., 2018; Acar 2018). Yem rasyonuna ilave edilecek olan yeni bir katkının balıklar üzerindeki etkilerinin belirlenmesinde büyüme performansı ile birlikte hematolojik ve serum biyokimyasal kan parametrelerinin incelenmesi balıkların sağlı durumu hakkında bize bilge vermektedir (Dawood ve ark., 2017).

Karabaş otunun literatürde antioksidan ve antimikrobiyal (Gülçin ve ark., 2004; Bouzouita ve ark., 2005; Cherrat ve ark., 2014) özellikleri bildirilmiştir. Bu özellikleri ile iyi bir yem katkı maddesi olarak gözükmektedir. Ancak literatürde karabaş otunun sazan balığı gelişimi üzerine etkisiyle ilgili herhangi bir çalışmaya rastlanılmamıştır. Bu çalışmada, sazan balığı yemlerine ilave edilen karabaş otu yağının büyüme performansı ve bazı kan parametreleri üzerine etkileri araştırılmıştır.

\section{Materyal ve Yöntem}

Deneme Yeri, Deney Sistemi ve Balık

Bu çalışma, Çanakkale Onsekiz Mart Üniversitesi Deniz Bilimleri ve Teknolojisi Fakültesi Canlı Kaynaklar Üretim Ünitesinde yürütülmüştür. Deney balıkları kapalı devre üretim sisteminde barındırılmıştır. Kapalı devre sistem çökeltme havuzu, kaba filtrasyon, kum filtre, biyolojik filtre ve 1sıtma-soğutma ünitesinden (Tuna Mac ${ }^{\circledR}$, Çanakkale) oluşmaktadır. Deneme $140 \mathrm{~L}$ hacmindeki fiberglas tanklarda yapılmış ve günlük olarak \%10-15 oranında su değişimi sağlanmıştır. Deneme ünitesinin aydınlatılmasında otomatik zamanlayıcılar kullanılmış ve 12 saat aydınlık; 12 saat karanlık 1şık periyodu uygulanmışı̧ı. Sazan balıkları Akdeniz Su Ürünleri Araştırma, Üretim Eğitim Enstitüsü Müdürlüğü'nden temin edilmiş olup 15 günlük adaptasyondan sonra rastgele olarak 3 tekrarlı olacak şekilde deneme tanklarına konmuşlardır. Deneme balıklarının ortalama ağırlıkları $10,88 \pm 0,90$ (ortalama \pm standart sapma) olarak belirlenmiştir. Denemede her bir tanka 30 balık konmuştur. Kontrol, $5 \mathrm{~g} / \mathrm{kg}$ karabaş otu yağ 1 ve $10 \mathrm{~g} / \mathrm{kg}$ karabaş otu yağ 1 olmak üzere toplamda üç grup için 270 adet sazan balığı kullanılmıştır. Bu çalışmanın Hayvan Deneyleri Etiği açısından uygun olduğu Çanakkale Onsekiz Mart Üniversitesi, Hayvan Deneyleri Yerel Etik Kurulu (Karar Numarası 2018/0105) tarafından onaylanmıştır.

\section{Deneme Yemleri}

Karabaş otu yağı KRK Gıda (Fatih/İstanbul) firmasından temin edilmiştir. Sazan balığı yemleri ticari rasyona uygun olarak $\% 35$ protein ve $\% 8$ yă içeriğine sahip olacak şekilde izokalorik ve izonitrojenik olarak hazırlanmıştır (Çizelge 1). Deneme yemlerinin hazırlanması için Çizelge 1 deki hammaddeler ve katkı maddeleri La Monferrina - P3 yem makinesinin karıştırma haznesi yardımıyla homojen oluncaya kadar karıştırılmıştır. Devamında bu karışıma su ilave edilmiş ve karıştırma işlemine bir süre daha devam edilmiştir. Karışım uygun kıvama geldikten sonra $2 \mathrm{~mm}$ boyutundaki ayna dan geçirilerek yemler hazırlanmıştır. Sonrasında nem oranı yüksek olan pelet yemlerin kurutma işlemi $40{ }^{\circ} \mathrm{C}$ lik hava sirkülasyonlu kurutma kabininde nem oranları \% 10 oluncaya kadar devam edilmiştir. Yem hammaddelerinin ve yemlerin besin değeri analizleri AOAC (1998)' e göre yapılmıştır.

Hamsi balık unu, hamsi balık yağı, yağsız soya fasulyesi küspesi, buğday unu, buğday nişastası, BHT Sibal A.Ş. (Sinop/Türkiye) den temin edilmiştir. Vitamin Karışımı: Vitamin A. 18,000 IU/kg yem; Vitamin D3. $2500 \mathrm{IU} / \mathrm{kg}$ yem; Vitamin E. $250 \mathrm{mg} / \mathrm{kg}$ yem Vitamin K3. $12 \mathrm{mg} / \mathrm{kg}$ yem; Vitamin B1. $25 \mathrm{mg} / \mathrm{kg}$ yem; Vitamin B2. $50 \mathrm{mg} / \mathrm{kg}$ yem; Vitamin B3. $270 \mathrm{mg} / \mathrm{kg}$ yem; Vitamin B6. 20 $\mathrm{mg} / \mathrm{kg}$ yem; Vitamin B12. 0,06 mg/kg yem; Vitamin C. $200 \mathrm{mg} / \mathrm{kg}$ yem; Folik asit. $10 \mathrm{mg} / \mathrm{kg}$ yem; Kalsiyum d-pantotenat. $50 \mathrm{mg} / \mathrm{kg}$ yem; Biyotin. $1 \mathrm{mg} / \mathrm{kg}$ yem; İnositol. $120 \mathrm{mg} / \mathrm{kg}$ yem; Kolin klorür. 2,000 mg/kg yem. Mineral Karışımı (mg/kg): Fe. 75,3 mg; Cu. 12,2 mg; Mn. 206 mg; Zn. 85 mg; I. 3 mg; Se. 0,350 mg; Co. 1 mg. Nitrojensiz Öz Madde (NÖM) = Kuru madde- (yağ+kül+protein). Enerji 23,6 kJ/g protein, $39,5 \mathrm{~kJ} / \mathrm{g}$ yağ, ve 17,0 kJ/g NFE' e göre belirlenmiştir.

\section{Balıklardan Kan Örneklerinin Alınması}

Deney balıkları 60 gün süreyle deneme yemleriyle beslenmiştir. Deneme sonunda 1 gün aç bırakılan balıklardan sonrasında kan örneklemesi yapılmıştır. Bu amaçla her bir tanktan 3 adet (9 balık/deneme grubu) olacak şekilde kan alınmıştır. Balıklar rastgele ve hızlıca deneme tanklarından 
yakalanmış ve en kısa süre içerisinde karanfil yağ1 $(20 \mathrm{mg} / \mathrm{L})$ bulunan $10 \mathrm{~L}$ lik plastik kova da bayıltılmıştır (Iversen ve ark., 2003). Bayıltma işleminden sonra kana mukoza karışmasını önlemek amacıyla balıkların anal yüzgecinin hemen arkası \%70 lik alkolle temizlenmiştir. Kan alımı için 2,5 $\mathrm{mL}$ lik plastik enjektör kullanılmış ve kaudal venadan kan alınmıştır. Kan örnekleri hematolojik analizler için $\mathrm{K}_{3}$ EDTA ve serum biyokimyası analizleri için jelli serum tüpleri içerisine alınmıştır. Serum analizleri için jelli tüplerdeki kan örnekleri $5000 \mathrm{~g}$ devirde 10 dakika santrifüj edilmiştir. Elde edilen serum $-80^{\circ} \mathrm{C}$ de analiz edilinceye kadar saklanmıştır.

Çizelge 1. Yem rasyonları ve kimyasal kompozisyonları

\begin{tabular}{|c|c|c|c|}
\hline Yem rasyon içeriği (\%) & $\mathbf{K}$ & $\begin{array}{c}5 \mathrm{~g} / \mathrm{kg} \\
\text { Karabaş otu yağı }\end{array}$ & $\begin{array}{c}10 \mathrm{~g} / \mathrm{kg} \\
\text { Karabaş otu yağı }\end{array}$ \\
\hline Balık unu & 30,00 & 30,00 & 30,00 \\
\hline Soya küspesi & 20,00 & 20,00 & 20,00 \\
\hline Buğday unu & 35,00 & 35,00 & 35,00 \\
\hline Mineral karışımı & 2,00 & 2,00 & 2,00 \\
\hline Vit karışımı & 1,00 & 1,00 & 1,00 \\
\hline Koruyucu (BHT) & 0,001 & 0,001 & 0,001 \\
\hline Nişasta & 5,999 & 5,999 & 5,999 \\
\hline Balık yağ1 & 6,00 & 5,50 & 5,00 \\
\hline Karabaş otu yağ1 & 0,00 & 0,50 & 1,00 \\
\hline \multicolumn{4}{|l|}{$\begin{array}{l}\text { Kimyasal komposizyon } \\
\text { (\%, Kuru madde) }\end{array}$} \\
\hline Protein & 35,15 & 35,16 & 35,15 \\
\hline Yağ & 8,40 & 8,39 & 8,41 \\
\hline Kül & 4,95 & 4,93 & 4,97 \\
\hline NÖM & 38,97 & 38,91 & 38,95 \\
\hline Enerji (GE) & 18,24 & 18,23 & 18,24 \\
\hline
\end{tabular}

Fiziksel ve Kimyasal Su Kalitesi Analizleri

Denemede sıcaklık, oksijen ve iletkenlik ölçümleri için YSI Pro2030 su analiz cihazı yardımıyla iki günde bir takip edilmiştir. Suyun pH ölçümleri ise HANNA (HI 2221) masa üstü pH metre ile üç günde bir yapılmıştır. Toplam Amonyak, Nitrit ve Nitrat Optizen POP UV/VIS spektrofotometre ile haftalık olarak ölçülmüştür.

Büyüme Performansi, Yemden Yararlanmanın Hesaplanması

Denemede büyüme performansı ve yemden yararlanmanın hesaplanmasında aşağıdaki formüller kullanılmıştır:

Yüzde Canlı Ağırlık Artışı CAA (\%) = (Son Ağırlık g - Başlangıç ağırlığı g ) / Başlangıç Ağırlığ1 x 100

Spesifik Büyüme Oranı: SBO $\left(\% \mathrm{Gün}^{-1}\right)=[\mathrm{Ln}($ Son ortalama ağırlık g) - Ln (Başlangıçtaki ortalama Ağırlık g)] / Deneme gün sayısı x 100

Yem Dönüşüm Oranı: YDO = Yem Tüketimi (g)/ Ağırlık Kazanımı (g)

Ekonomik dönüşüm indeksi $=$ Yemin fiyatı $\mathrm{x}$ FCR

Hematolojik Analizler

Hematolojik analizlerden kırmızı kan hücre sayısı (RBC), hematokrit ve hemoglobin analizleri otomatik kan sayım cihazı (Mindray/BC 3000 Plus) ile yapılmıştır. Bu cihaz daha önce laboratuvarımızdaki balık çalışmalarında kullanılmıştır (Yılmaz ve ark., 2018; Yılmaz ve Ergün 2018). Cihaz analizlerden önce manuel yöntemler ile kıyaslanarak sazan balıkları için kalibre edilmiştir.

Biyokimyasal Analizler

Serum biyokimyası analizleri ticari kit (Bioanalytic) kullanılarak spektrofotometrik olarak (Optizen POP UV/VIS) yapılmıştır (Yılmaz ve Ergün, 2012). Bu çalışmada serumda glikoz, albümin, globülin, toplam protein, trigliserit, kolesterol, GOT, GPT, LDH ve ALP biyokimyasal parametreleri belirlenmiştir. 


\section{Istatistiksel Analizler}

Deneme gruplarından elde edilen verilere tek yönlü varyans analizi (ANOVA) uygulanmıştır. Verilerin normal dağılım göstermesi ve homejen olması durumunda Tukey çoklu karşılaştırma testi, normal dağılım göstermeyen, homejen verilerin karşılaştırılmasında Kruskal-Wallis testi ve homojen olmayan verilerin karşılaştırılmasında Tamhane testi kullanılmıştır. İstatistiksel analizler SPSS 19 (IBMM SPSS Statistics 19) programı kullanılarak p<0,05 önemlilik seviyesinde değerlendirilmiştir.

\section{Bulgular ve Tartışma}

Fiziksel ve Kimyasal Su Kalitesi Bulguları

Deneme süresince, su sicaklığ $25,2-26,3{ }^{\circ} \mathrm{C}$, oksijen 7,2-8,0 mg/l, iletkenlik 415-440 $\mu \mathrm{s} \mathrm{cm}^{-1}$, pH 7,1-7,8, toplam amonyak $0,010-0,016 \mathrm{mg} / 1$, Nitrit $0,01-0,03 \mathrm{mg} / 1$ ve Nitrat $0,1-0,3 \mathrm{mg} / 1$ olarak tespit edilmiştir.

\section{Büyüme Performansı Bulguları}

Besleme denemesi sonunda elde edilen büyüme performansı ve yem değerlendirme bulguları Çizelge 2 de gösterilmiştir. Yeme $5 \mathrm{~g} / \mathrm{kg}$ oranında karabaş otu yağ artışını (\%) ve spesifik büyüme oranını (SBO) arttırdı̆̆ı, yem dönüşüm oranını (YDO) ise azalttığı belirlenmiştir $(\mathrm{p}<0,05)$.

Çizelge 2. Deneme sonunda gruplara göre elde edilen büyüme performansı ve yem değerlendirme bulgular1

\begin{tabular}{|c|c|c|c|}
\hline & \multicolumn{3}{|c|}{ Deneme grupları } \\
\hline & Kontrol & $5 \mathrm{~g} / \mathrm{kg}$ & $10 \mathrm{~g} / \mathrm{kg}$ \\
\hline & & Karabaş otu yağı & Karabaş otu yağı \\
\hline $\begin{array}{l}\text { Deneme başı ortalama balık } \\
\text { ăğırlı̆ğ }(\mathrm{g})\end{array}$ & $10,29 \pm 0,27^{\mathrm{a}}$ & $10,38 \pm 0,22^{\mathrm{a}}$ & $10,98 \pm 0,87^{\mathrm{a}}$ \\
\hline $\begin{array}{l}\text { Deneme sonu ortalama balık } \\
\text { ağırlığı (g) }\end{array}$ & $24,74 \pm 0,43^{\mathrm{b}}$ & $30,64 \pm 1,50^{\mathrm{a}}$ & $25,77 \pm 1,45^{\mathrm{b}}$ \\
\hline Canlı ağırlık artışı (\%) & $140,54 \pm 2,55^{b}$ & $194,10 \pm 7,45^{\mathrm{a}}$ & $135,70 \pm 6,15^{b}$ \\
\hline YDO & $1,04 \pm 0,02^{\mathrm{a}}$ & $0,78 \pm 0,01^{\mathrm{b}}$ & $1,12 \pm 0,15^{\mathrm{a}}$ \\
\hline $\begin{array}{l}\text { SBO } \\
\left(\% \text { gün }^{-1}\right)\end{array}$ & $1,46 \pm 0,02^{b}$ & $1,78 \pm 0,05^{\mathrm{a}}$ & $1,43 \pm 0,04^{b}$ \\
\hline EDI & 6,24 & 4,89 & 7,28 \\
\hline
\end{tabular}

$\mathrm{n}=3$, Ortalama \pm standart hata. Aynı satırda farklı harflerle gösterilen gruplar istatistiksel açıdan farklıdır $(\mathrm{P} \leq 0,05)$.

YDO: Yem dönüşüm oran1, SBO: Spesifik büyüme oran1, EDİ: Ekonomik dönüşüm indeksi

\section{Hematolojik Bulgular}

Deneme sonunda balıkların RBC, Hb ve Hct bulguları Çizelge 3'de verilmiştir. Karabaş otu yağının sadece $\mathrm{Hb}$ değerinde önemli değişimlere neden olduğu belirlenmiştir. Yeme $5 \mathrm{~g} / \mathrm{kg}$ oranında karabaş otu yağı ilavesi kontrol ve $10 \mathrm{~g} / \mathrm{kg}$ karabaş otu ilaveli gruba göre $\mathrm{Hb}$ değerini önemli oranda $\operatorname{arttırmıştır~}(\mathrm{p}<0,05)$.

Çizelge 3. Deneme sonunda balıkların RBC, $\mathrm{Hb}$ ve Hct bulguları

\begin{tabular}{ccc} 
Kontrol & Deneme grupları & \\
& $\mathbf{5} \mathbf{g} / \mathbf{k g}$ & $\mathbf{1 0} \mathbf{g} / \mathbf{k g}$ \\
& Karabaş otu yağı & Karabaş otu yağı \\
\hline $2,08 \pm 0,18^{\text {a }}$ & $2,38 \pm 0,06^{\text {a }}$ & $2,30 \pm 0,05^{\text {a }}$ \\
$7,93 \pm 0,58^{\mathrm{b}}$ & $10,28 \pm 0,79^{\mathrm{a}}$ & $8,60 \pm 0,29^{\mathrm{b}}$ \\
$30,57 \pm 1,32^{\mathrm{a}}$ & $34,07 \pm 1,23^{\mathrm{a}}$ & $33,00 \pm 0,72^{\mathrm{a}}$
\end{tabular}

\begin{tabular}{lccc}
\hline RBC $\left(\mathbf{1 0}^{\mathbf{6}} \mathbf{~ m m}^{-3}\right)$ & $2,08 \pm 0,18^{\text {a }}$ & $2,38 \pm 0,06^{\text {a }}$ & $2,30 \pm 0,05^{\text {a }}$ \\
Hb (g/dL) & $7,93 \pm 0,58^{\text {b }}$ & $10,28 \pm 0,79^{\text {a }}$ & $8,60 \pm 0,29^{\text {b }}$ \\
Het (\%) & $30,57 \pm 1,32^{\text {a }}$ & $34,07 \pm 1,23^{\text {a }}$ & $33,00 \pm 0,72^{\text {a }}$ \\
\hline n=9, Ortalama \pm standart hata. RBC: kırmızı kan hücre sayıs1, Hb: hemoglobin, Hct: Hematokrit. Aynı satırda farklı harflerle \\
gösterilen gruplar istatistiksel açıldan farklıdır (P $\leq 0,05)$.
\end{tabular}




\section{Serum Biyokimyası Bulgular}

Deneme sonunda balıkların serum biyokimyası bulguları Çizelge 4'de verilmiştir. Yeme karabaş otu yağı ilavesi test edilen serum biyokimyası parametrelerinden sadece serum glikoz düzeylerinde önemli değişimlere neden olmuştur. Serum glikozun yeme karabaş otu yağ 1 ilavesiyle istatistiksel açıdan önemli derecede azaldığı belirlenmiştir $(p<0,05)$. Serum trigliserit değerlerinin ise sadece karabaş otu yağı grupları arasında istatistiksel açıdan farklılık gösterdiği $(p<0,05)$ kontrol grubuna göre önemli bir değişimin olmadığı tespit edilmiş̧tir ( $\mathrm{p}>0,05)$.

Çizelge 4. Deneme sonunda balıkların serum biyokimyası bulguları

\begin{tabular}{|c|c|c|}
\hline \multicolumn{3}{|c|}{ Deneme grupları } \\
\hline Kontrol & $5 \mathrm{~g} / \mathrm{kg}$ & $10 \mathrm{~g} / \mathrm{kg}$ \\
\hline & Karabaş otu yağı & Karabaş otu yağı \\
\hline $113,64 \pm 7,51^{\mathrm{a}}$ & $82,23 \pm 6,69^{b}$ & $62,35 \pm 10,42^{b}$ \\
\hline $6,08 \pm 0,19^{\mathrm{a}}$ & $6,76 \pm 0,25^{\mathrm{a}}$ & $6,14 \pm 0,29^{\mathrm{a}}$ \\
\hline $0,08 \pm 0,01^{\mathrm{a}}$ & $0,12 \pm 0,02^{\mathrm{a}}$ & $0,08 \pm 0,02^{\mathrm{a}}$ \\
\hline $5,99 \pm 0,19^{\mathrm{a}}$ & $6,64 \pm 0,26^{\mathrm{a}}$ & $6,06 \pm 0,29^{a}$ \\
\hline $53,99 \pm 5,05^{\mathrm{ab}}$ & $38,41 \pm 5,16^{\mathrm{b}}$ & $70,83 \pm 9,71^{\mathrm{a}}$ \\
\hline $139,27 \pm 5,64^{\mathrm{a}}$ & $132,29 \pm 7,50^{\mathrm{a}}$ & $135,65 \pm 4,37^{\mathrm{a}}$ \\
\hline $159,10 \pm 11,79^{\mathrm{a}}$ & $164,89 \pm 10,19^{\mathrm{a}}$ & $164,98 \pm 6,10^{\mathrm{a}}$ \\
\hline $15,42 \pm 1,67^{\mathrm{a}}$ & $16,88 \pm 1,94^{\mathrm{a}}$ & $20,30 \pm 1,58^{\mathrm{a}}$ \\
\hline $862,18 \pm 54,56^{\mathrm{a}}$ & $806,46 \pm 85,94^{\mathrm{a}}$ & $806,09 \pm 45,81^{\mathrm{a}}$ \\
\hline $88,75 \pm 16,00^{\mathrm{a}}$ & $92,24 \pm 12,91^{\mathrm{a}}$ & $132,94 \pm 33,15^{\text {a }}$ \\
\hline
\end{tabular}

$\mathrm{Bu}$ çalışmada sazan balığı yemlerine $5 \mathrm{~g} / \mathrm{kg}$ oranında karabaş otu yağı ilavesi balıkların büyüme performansını ve hemoglobin değerini arttırmış ve serum glikoz düzeyini azaltmıştır. Ayrıca, ekonomik analiz (EDI) sonucuna bakacak olursak yeme $5 \mathrm{~g} / \mathrm{kg}$ karabaş otu yağı ilavesi kontrole göre daha ekonomik bulunmuştur. Elde edilen bu sonuçlar balık yemlerinde karabaş otu yağının kullanılabileceğini göstermiştir. Benzer olarak yeme ilave edilen tıbbi bitki veya baharatların büyüme performansını arttırdığı önceki çalışmalarda da rapor edilmiştir (Adel ve ark., 2015; Van Hai, 2015). Tıbbi bitki veya baharatların büyüme performansı üzerindeki bu etkisi sindirim enzimlerini aktive etmeleri sonucu besin emilimindeki artışlarla ilişkilendirilmiştir (Yılmaz ve ark., 2013; Yılmaz ve Ergün 2014). Ancak, bu yem katkılarının balıklar üzerindeki yararlı etkileri optimum dozlarda gerçekleşmektedir. Yemlerde yüksek oranlarda tıbbi bitki veya baharat ilavelerinin ise büyüme performansı ve balık sağlığı üzerindeki etkileri olumsuz olabilmektedir. Örneğin tilapia yemlerine farklı oranlarda kimyon baharatı ilave edilen bir çalışmada, \% 1 oranında kimyonun hastalık direncini arttırdığı, ancak \% 1 in üzerinde bu etkinin görülmediği belirlenmiştir (Yılmaz ve ark., 2013). Farklı bir çalışmada tilapia yemlerine demir dikeni (Tribulus terrestris) ilavesi optimum dozlarda (200-400 $\mathrm{mg} / \mathrm{kg}$ ) balık gelişimi ve hastalık direncini olumlu etkilerken, artan oranlar da bu etki gerçekleşmemiştir (Y1lmaz ve ark., 2014).

Hematolojik ve serum biyokimyası parametreleri balık sağlının önemli birer göstergesidir (Yılmaz ve ark., 2016). Bu çalışmada sazan balığı yemlerine $5 \mathrm{~g} / \mathrm{kg}$ oranında karabaş otu yağ balıkların hematolojik parametrelerinden hemoglobin değerinde önemli bir artış sağlamıştır. Benzer sonuçlar farklı çalışmalarda elde edilmiştir (Ji ve ark., 2007; Baba ve ark., 2016). Ayrıca, sazan balığ1 için elde ettiğimiz RBC, Hct ve Hb bulgularının bu balık için bildirilmiş olan referans değerleri [RBC: 0,65-4,66 $10^{6} \mathrm{~mm}^{-3}$, Hct: \%21-40 Hb: 6,3-12,4 g/dL] aralı̆̆ında olduğu görülmektedir (Field ve ark., 1943; Tripathi ve ark., 2004; Baba ve ark., 2016).

Bu çalışmada karabaş otu yağı katkılı yemlerle beslenen balıkların kan proteinleri, lipitleri ve enzimlerinin kontrole göre önemli bir değişim göstermedikleri belirlenmiştir. Genel balık sağlığının değerlendirilmesinde kullanılan bu parametrelerin değişmemiş olması önemlidir. Ancak, yeme karabaş 
otu yağı ilavesi balıkların glikoz düzeylerini etkilemiştir. Kan glikozu balıkların beslenmesi ve stres durumuna bağlı olarak değişebilen önemli bir fizyolojik göstergedir. Özellikle balıkların ellenmesinde, taşınmasında, oksijen azlığında, hastalıklarda ve yoğun stoklamada artış göstermektedir (MCdonald ve Milligan, 1992). Kanda artış gösteren glikoz miktarı kaslarda kortizolün, karaciğerde ise adrenalin ve stres hormonlarının tetiklenmesine neden olmaktadır (Morgan ve Iwama, 1997). Literatürde sazan balıkları (Cyprinus carpio) için glikozun normal değer aralığ $57-230 \mathrm{mg} / \mathrm{dL}$ olarak bildirilmiştir (Field ve ark., 1943). Bu çalışmada tüm deneme gruplarının serum glikoz düzeylerinin normal değerlerde olduğu görülmektedir. Ancak, karabaş otu yağ1 ilaveli gruplarda kan glikozunun kontrol grubuna göre önemli oranda azaldığı bulunmuştur. Bu durum karabaş otu yağının hipoglisemik etkisiyle açıklanabilir (Gamez ve ark., 1987). Benzer olarak tıbbi bitki veya baharatların glikoz azaltıcı etkisi farklı çalışmalarda da bildirilmiştir (Wu ve ark., 2013; Baba ve ark., 2016; Yılmaz ve ark., 2016).

\section{Sonuç ve Öneriler}

Sonuç olarak, bu çalışmada karabaş otu yağının sazan balığı yemlerine $5 \mathrm{~g} / \mathrm{kg}$ oranında ilavesi balıkların kan parametrelerine olumsuz bir etki göstermeksizin büyüme performansını arttırmıştır. İleriki çalışmalarda karabaş otu yağının farklı balık türlerinde farklı dozlarının araştırılmasına ihtiyaç vardır.

\section{Kaynaklar}

Acar, Ü., 2018. Sarı kantaron (Hypericum perforatum) yağının sazan yavrularının (Cyprinus carpio) büyüme performansı ve bazı kan parametreleri üzerine etkisi. Alınteri Zirai Bilimler Dergisi. 33(1): 21-27.

Adel, M., Safari, R., Pourgholam, R., Zorriehzahra, J., Esteban, M.Á., 2015. Dietary peppermint (Mentha piperita) extracts promote growth performance and increase the main humoral immune parameters (both at mucosal and systemic level) of Caspian brown trout (Salmo trutta caspius Kessler, 1877). Fish Shellfish Immunology. 47(1): 623-629.

Baba, E., Acar, Ü., Öntaş, C., Kesbiç, O.S., Yilmaz, S., 2016. The use of Avena sativa extract against Aeromonas hydrophila and its effect on growth performance, hematological and immunological parameters in common carp (Cyprinus carpio). Italian Journal of Animal Science. 15(2): 325-333.

Baba, E., Acar, Ü., Yılmaz, S., Öntaş, C., Kesbiç, O.S., 2017. Pre-challenge and post-challenge haematoimmunological changes in Oreochromis niloticus (Linnaeus, 1758) fed argan oil against Lactococcus garvieae. Aquaculture Research. 48(8): 4563-4572.

Bouzouita, N., Kachouri, F., Hamdi, M., Chaabouni, M.M., Aissa, R.B., Zgoulli, S., Lognay, G.C., 2005. Volatile constituents and antimicrobial activity of Lavandula stoechas L. oil from Tunisia. Journal of Essential Oil Research. 17(5): 584-586.

Cherrat, L., Espina, L., Bakkali, M., Pagán, R., Laglaoui, A., 2014. Chemical composition, antioxidant and antimicrobial Properties of Mentha pulegium, Lavandula stoechas and Satureja calamintha scheele essential oils and an evaluation of their bactericidal effect in combined processes. Innovative Food Science Emerging Technologies. 22: 221-229.

da Cunha, J.A., Heinzmann, B.M., Baldisserotto, B., 2018. The effects of essential oils and their major compounds on fish bacterial pathogens-a review. Journal of Applied Microbiology. 125: 328-344.

Dawood, M.A., Koshio, S., Esteban, M.Á., 2017. Beneficial roles of feed additives as immunostimulants in aquaculture: a review. Reviews in Aquaculture.

Ezzat Abd El-Hack, M., Alagawany, M., Ragab Farag, M., Tiwari, R., Karthik, K., Dhama, K., Adel, M., 2016. Beneficial impacts of thymol essential oil on health and production of animals, fish and poultry: a review. Journal of Essential Oil Research. 28(5): 365-382.

FAO, 2015. Total Fishery Production. Fishery Statistics, Fishstat Plus.

Field, J.B., Elvehjem, C.A., Juday, G., 1943. A study of the blood constituents of carp and trout. Journal of Biological Chemistry. 148: 261-269.

Gamez, M.J., Jimenez, J., Risco, S., Zarzuelo, A., 1987. Hypoglycemic activity in various species of the genus lavandula. Part 1: Lavandula stoechas L. and Lavandula multifida L. Pharmazie. 42: 706-707.

Gülçin, İ., Şat, İ.G., Beydemir, Ş., Elmastaş, M., Küfrevioğlu, Ö.İ., 2004. Comparison of antioxidant activity of clove (Eugenia caryophylata Thunb) buds and lavender (Lavandula stoechas L.). Food Chemistry. 87(3): 393-400. 
Hoole, D., Bucke, D., Burgess, P., Wellby, I. (Eds.)., 2008. Diseases of carp and other cyprinid fishes. John Wiley \& Sons.

Iversen, M., Finstad, B., McKinley, R.S., Eliassen, R.A., 2003. The efficacy of metomidate, clove oil, Aqui-S and Benzoak ${ }^{\circledR}$ as anaesthetics in Atlantic salmon (Salmo salar L.) smolts, and their potential stressreducing capacity. Aquaculture. 221(1-4): 549-566.

Ji, S.C., Takaoka, O., Jeong, G.S., Lee, S.W., Ishimaru, K., Seoka, M., Takii, K., 2007. Dietary medicinal herbs improve growth and some non-specific immunity of red sea bream Pagrus major. Fisheries Science. 73(1): 63-69.

McDonald, D.G., Milligan, C.L., 1992. Chemical Properties of the Blood. In: Hoar W.S., Randall D.J. and Farrel A.P., Eds. Fish Physiology: The Cardiovascular System Part B volume XII. Academic Press Inc., California. 56-113.

Morgan, J.D., Iwama, G.K., 1997. Measurements of Stressed States in the Field. In: Iwama G.K.; Pickering A.D.; Sumpter J.P.; Schreck C.B., Eds. Fish Stress and Health in Aquaculture. Cambridge University Press Cambridge. 247-270.

Ng, W.K., Koh, C.B., 2017. The utilization and mode of action of organic acids in the feeds of cultured aquatic animals. Reviews in Aquaculture. 9(4): 342-368.

AOAC, 1998. Official Methods of Analysis of AOAC International, Gaithersburg MD.

Ramudu, K.R., Dash, G., 2013. A review on herbal drugs against harmful pathogens in aquaculture. American Journal of Drug Discovery and Development. 3(4): 209-219.

Syahidah, A., Saad, C.R., Daud, H.M., Abdelhadi, Y.M., 2015. Status and potential of herbal applications in aquaculture: A review. Iranian Journal of Fisheries Sciences. 14(1): 27-44.

Tripathi, N.K., Latimer, K.S., Burnley, V.V., 2004. Hematologic reference intervals for koi (Cyprinus carpio), including blood cell morphology, cytochemistry, and ultrastructure. Veterinary Clinical Pathology. 33(2): 74-83.

Van Hai, N., 2015. The use of medicinal plants as immunostimulants in aquaculture: a review. Aquaculture. 446: $88-96$.

Wu, Z.X., Pang, S.F., Chen, X.X., Yu, Y.M., Zhou, J.M., Chen, X., Pang, L.J., 2013. Effect of coriolus versicolor polysaccharides on the hematological and biochemical parameters and protection against Aeromonas hydrophila in allogynogenetic crucian carp (Carassius auratus gibelio). Fish physiology and Biochemistry. 39(2): 181-190.

Yılmaz, S., Ergün, S., Kaya, H., Gürkan, M., 2014. Influence of Tribulus terrestris extract on the survival and histopathology of Oreochromis mossambicus (Peters 1852) fry before and after Streptococcus iniae infection. Journal of Applied Ichthyology. 30: 994-1000.

Y1lmaz, S., Ergün, S., 2012. Effects of garlic and ginger oils on hematological and biochemical variables of sea bass Dicentrarchus labrax. Journal of Aquatic Animal Health. 24: 219-224.

Y1lmaz, S., Ergün, S., 2018. Trans-cinnamic acid application for rainbow trout (Oncorhynchus mykiss): I. effects on haematological, serum biochemical, non-specific immune and head kidney gene expression responses. Fish and Shellfish Immunology. 78: 140-157.

Yılmaz, S., Ergün, S., Çelik, E.Ş., 2016. Effect of dietary spice supplementations on welfare status of sea bass Dicentrarchus labrax L. Proceedings of the National Academy of Sciences India Section B: Biological Sciences. 86: 229-237.

Yılmaz, S., Ergün, S., Soytaş, N., 2013. Dietary supplementation of cumin (Cuminum cyminum) preventing streptococcal disease during first-feeding of Mozambique tilapia (Oreochromis mossambicus). Journal of BioScience Biotechnology. 2(2): 117-124.

Yilmaz, S., Ergün, S., Yı1t, M., 2018. Effects of dietary FARMARIN® XP supplement on immunological responses and disease resistance of rainbow trout (Oncorhynchus mykiss). Aquaculture. 496: 211-220. 